\title{
Comparison of Functional Outcomes after Powered Intracapsular Tonsillectomy with Adenoidectomy and Conventional Extracapsular Tonsillectomy with Adenoidectomy for Pediatric Obstructive Sleep Apnea
}

\author{
Jae-Min Jeon, Jeong-Rok Kim, Seung-Hwan Bang, Jong-Geun Lee, Jae-Min Shin, \\ Il-Ho Park, Jeong-Soo Woo, Sung-Won Chae, and Jae-Jun Song ${ }^{\mathbb{D}}$ \\ Department of Otorhinolaryngology-Head and Neck Surgery, Korea University Medical Center, Korea University College of Medicine, Seoul, Korea
}
소아 수면무호흡 환자의 편도, 아데노이드 절제술에서 전동식 피막 내 편도전절제술과
전통적 피막 외 편도전절제술의 비교

전재민·김정록·방승환·이종근· 신재민· 박일호· 우정수·채성원· 송재준

고려대학교 의과대학 이비인후-두경부외과학교실

Received May 6, 2019

Revised July 1,2019

Accepted July 4, 2019

Address for correspondence

Jae-Jun Song, MD, PhD

Department of Otorhinolaryngology-

Head and Neck Surgery,

Korea University Medical Center,

Korea University College of

Medicine, 148 Gurodong-ro,

Guro-gu, Seoul 08308, Korea

Tel $+82-2-2626-3191$

Fax $+82-2-868-0475$

E-mail jjsong23@gmail.com
Background and Objectives This study was investigated to compare the clinical outcomes and complications of powered intracapsular tonsillectomy and adenoidectomy (PITA) with those of conventional extracapsular tonsillectomy and adenoidectomy (ECTA) in treatment of pediatric obstructive sleep apnea (OSA).

Subjects and Method Eighty-one children with adenotonsillar hyperplasia underwent tonsillectomy and adenoidectomy (46 PITA and 35 ECTA) from December 2016 to July 2017 for OSA. The choice of surgical procedure (PITA vs. ECTA) was determined by the number of episodes of acute tonsillitis. The quality of life measurement was performed using Korean Obstructive Sleep Apnea Survey (KOSA-18) score. Postoperative bleeding was assessed as number of revisit or readmission. Postoperative pain was evaluated by visual analog scale (VAS) at postoperative day 1,3 , and 7.

Results PITA and ECTA significantly reduced KOSA-18 scores postoperatively $(p<0.01, p<0.01$, respectively) and were equally effective in pediatric OSA treatment. Postoperative bleeding was lower in the PITA group, but there was no statistical difference due to small number of cases. VAS score for postoperative pain was significantly lower in the PITA group at day 1,3 , and 7 ( $p=0.03$, $p<0.01$, and $p<0.01$, respectively).

Conclusion PITA is effective in pediatric OSA treatment with less morbidity, and less complications. Korean J Otorhinolaryngol-Head Neck Surg 2020;63(4):167-71

Key Words Pediatrics · Postoperative complications · Sleep apnea, obstructive · Surgical procedures, operative $\cdot$ Tonsillectomy.

\section{Introduction}

Tonsillectomy has been widely done for many years in the

This is an Open Access article distributed under the terms of the Creative Commons Attribution Non-Commercial License (https://creativecommons.org/licenses/by-nc/4.0) which permits unrestricted non-commercial use, distribution, and reproduction in any medium, provided the original work is properly cited. otolaryngologic fields. Complications of this operation are bleeding, dehydration, pain, and oral feeding discomfort. Conventional extracapsular tonsillectomy and adenoidectomy (ECTA) means total removal of tonsillar tissue, including capsule of tonsils. ${ }^{1)}$ On the other hand, intracapsular tonsillectomy preserves the tonsillar capsule, which results in less postoper- 
ative pain and faster recovery than ECTA. ${ }^{2)}$ There are several technique used for intracapsular tonsillectomy; however the use of a powered microdebrider to remove tonsils was first reported by Koltai, et al. ${ }^{3)}$ In this technique, the microdebrider removes tonsil, with leaving the lymphatic tissue on the capsule. This preserved tissue and tonsillar capsule function as a "biologic dressing," which protects the pharyngeal muscles overlying the tonsillar fossa. ${ }^{4}$ However, powered intracapsular tonsillectomy and adenoidectomy (PITA) is not performed in patients with recurrent tonsillitis due to the possibility of residual tonsils.

The large tonsils and adenoids can obstruct the pharyngeal airway and consequently cause obstructive sleep apnea (OSA), which is especially important in children. Therefore, adenotonsillectomy is an effective treatment for pediatric OSA and the application of PITA for the treatment of OSA has been reported in many studies. ${ }^{5-7)}$ However, the efficacy of PITA is still on debate. ${ }^{8)}$ There is also a lack of studies that directly compare PITA using microdebrider and ECTA's functional outcomes let alone prospective studies.

The study was done to compare the clinical outcomes and complications of PITA with those of ECTA in treatment of pediatric OSA. We hypothesized that PITA is an effective, safe and less painful treatment in pediatric OSA patients and we want to prove these advantages by comparing with ECTA.

\section{Subjects and Method}

\section{Study population}

A prospective study was conducted following the approval of the Institutional Review Board at Korea University Medical Center (No. MD16063-001). Eighty-one children undergoing tonsillectomy and adenoidectomy for OSA (46 in the PITA and 35 in the ECTA group) at Korea University Guro Hospital were enrolled in the study from December 2016 to July 2017. The choice of surgical procedure (PITA vs. ECTA) was determined by the number of episodes of acute tonsillitis. Children with a clear history of recurrent tonsillitis (i.e., 7 episodes/year over 1 year; 5 episodes/year for 2 years or 3 episodes/year over 3 years) underwent ECTA, ${ }^{9)}$ on the other hand, children with OSA and no clear history of recurrent tonsillitis underwent PITA. Children with neurological deficits or craniofacial anomaly were excluded in this study. We examined the size of the tonsils and adenoids of all patients and graded using Friedman Grading Scale and Clemens \& McMurray Grading Scale.

\section{Surgical technique}

All children underwent adenotonsillectomy under general anesthesia. McIvor mouth gag was used for better exposure. To avoid of the uvula injury, rubber tube was inserted into the nasal cavity, and it retracted uvula. PITA was performed by using a microdebrider (Medtronic Xomed Inc., Jacksonville, FL, USA). This device was turned to the oscillating mode with a speed $1500 \mathrm{rpm}$ for intracapsular tonsillectomy. Dissection was done until the internal capsule plane was exposed. On the other hand, tonsil was removed using a monopolar electrocoagulator (Valleylab Inc., Jacksonville, FL, USA) in the ECTA group.

Adenoidectomy was done by using microdebrider in both groups. Bleeding control was done by bipolar electrocoagulator for the tonsillectomy and by packing gauze soaked with $10 \%$ hydrogen peroxide for the adenoidectomy. The soaked gauze was removed after 15 minutes. Posterior nasal packing made by Merocel $^{\circledR}$ (polyvinyl acetate sponge, Medtronic Xomed Inc.) was performed at the end of the operation and was removed 6 hours after surgery.

\section{Outcome assessment}

We measured the efficacy of treatment by using Korean Obstructive Sleep Apnea-18 Survey (KOSA-18) ${ }^{10,11)}$ to the parents before and 1 month after surgery. KOSA-18 is a questionnaire designed to assess the quality of life associated with sleep in children. KOSA-18 consists of 18 questions, which are divided into five subgroups of sleep, physical symptoms, emotional symptoms, daytime life, and caregiver status, ranging from 1 (none) to 7 (always), so the total score is evaluated from 18 to 126. According to the total KOSA-18 score, it is considered that there is mild $(<60)$, moderated $(60-80)$, and severe $(>80)$ decline quality of life.

We classified postoperative complications into two aspects-tonsillectomy site bleeding and postoperative pain. Bleeding was assessed as number of revisit, readmission and/or reoperation to control bleeding. Postoperative pain was evaluated by visual analog scale (VAS) to the parents in the 1,3 , and 7 days after operation.

\section{Statistical analysis}

Statistical analysis was performed using SPSS version 22.0 software (SPSS Inc., IBM Company, Armonk, NY, USA). The age, OSA-18 score, and VAS score were analyzed by the MannWhitney U-test or Wilcoxon singed Ranks test. The sex, size of tonsil and adenoid, and the number of cases presented with 
bleeding were analyzed by the chi-square test or Fisher's exact test. Statistical significance was defined as a $p<0.05$.

\section{Results}

A total of 81 patients participated in the study, 46 of whom were in the PITA group, and 35 of whom were in the ECTA group. Demographic characteristics of patients were shown in Table 1. There was male dominant in both groups. A mean age of patients was 7.1 years in PITA group and 8.3 years in ECTA group. However, there was no statistical difference between the two groups for age and sex. There was a statistical difference between two groups in terms of tonsil size. Tonsil size of grade 3 or 4 was more common in the PITA group, but there was no difference in adenoid size between two groups (Table 1). Polysomnography was not performed on any of the subjects.

The severity of OSA was assessed by measuring the patients' quality of life using the KOSA-18 questionnaire. The preoperative KOSA-18 score was 73.8 in the PITA group, and 58.6 in the ECTA group. However, there was no statistically significant difference of preoperative KOSA-18 between PITA and ECTA group ( $p=0.08$ ). The postoperative KOSA-18 score was 28.5 in the PITA group, and 33.2 in the ECTA group respectively. Significant reduction of KOSA-18 scores was shown in the both groups after operation $(p<0.01, p<0.01$ respectively; Fig. 1).

Postoperative pain was evaluated by VAS score. The average score at postoperative day 1, 3, and 7 were significantly lower in the PITA group compared to the ECTA group ( $p=0.03, p<0.01$, and $p<0.01$ respectively; Fig. 2).

Postoperative bleeding was 1 case in the PITA group, and 2 cases in the ECTA group (Table 2). All 3 cases had bleeding on tonsillectomy sites. One case in the ECTA group needed readmission to control bleeding, but there was no case of reoperation. Although bleeding was more common in the ECTA group, there was no significantly difference.

\section{Discussion}

Because obstruction of the airway due to hypertrophy of the tonsils and adenoids is the main cause of OSA in children, adenotonsillectomy is the first treatment option in pediatric OSA. It can relieve airway obstruction associated with sleep. ${ }^{12,13)}$

Several attempts have been made to perform surgery using different tools and technology. However, there is still a
Table 1. Patient characteristics $(n=81)$

\begin{tabular}{lccc}
\hline Characteristics & PITA $(\mathrm{n}=46)$ & ECTA $(\mathrm{n}=35)$ & p-value \\
\hline $\begin{array}{c}\text { Mean age } \pm \text { standard } \\
\text { deviation (min-max) }\end{array}$ & $\begin{array}{c}7.1 \pm 2.2 \\
(4-12)\end{array}$ & $\begin{array}{c}8.3 \pm 2.9 \\
(3-16)\end{array}$ & 0.067 \\
Number of males (\%) & $28(60.9)$ & $23(65.7)$ & 0.655 \\
Tonsil size, number (\%) & & & $0.004^{*}$ \\
I & $1(2.2)$ & $2(5.7)$ & \\
II & $0(0)$ & $4(11.4)$ & \\
III & $9(19.6)$ & $13(37.1)$ & \\
IV & $36(78.3)$ & $16(45.7)$ & \\
Adenoid size, number (\%) & & & \\
I & $2(4.3)$ & $4(11.4)$ & \\
II & $9(19.6)$ & $11(31.4)$ & \\
III & $21(45.7)$ & $16(45.7)$ & \\
IV & $14(30.4)$ & $4(11.4)$ & \\
\hline
\end{tabular}

* $<$ <0.05. PITA: powered intracapsular tonsillectomy and adenoidectomy, ECTA: extracapsular tonsillectomy and adenoidectomy.

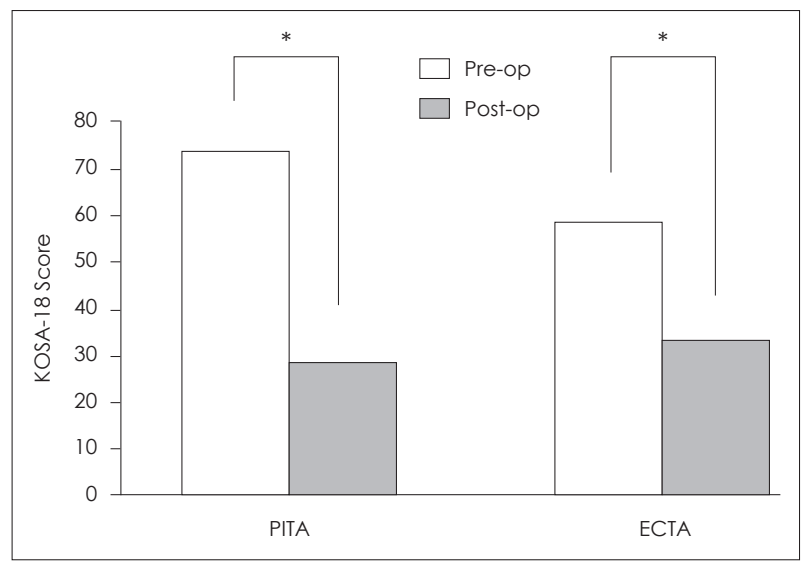

Fig. 1. Preoperative and postoperative KOSA-18 scores in PITA and ECTA groups. ${ }^{*} p<0.05$. PITA: powered intracapsular tonsillectomy and adenoidectomy, ECTA: extracapsular tonsillectomy and adenoidectomy, KOSA-18: Korean Obstructive Sleep Apnea-18 Survey.

dilemma for efficacy and safety. ${ }^{14)}$ The first introduction of PITA was reported by Koltai, et al. ${ }^{3)}$ and several studies have proven the effectiveness and safety of this procedure. .,14) $^{2}$

Sleep apnea is closely related to quality of life because it induces daytime sleepiness and depressive mood. ${ }^{15,16)}$ In our study, we found that KOSA-18 scores were significantly reduced regardless of intracapsular or extracapsular tonsillectomy. It is consistent with the previous meta-analysis study. ${ }^{1)}$ These results showed that quality of life was improved after surgery in pediatric patients. Although it is a subjective evaluation method, it can be considered as a meaningful result.

Because tonsillar capsule is left during PITA, the underlying vessels can be preserved. Therefore, PITA reduces the risk of postoperative bleeding. ${ }^{17)}$ Incidence of postoperative 


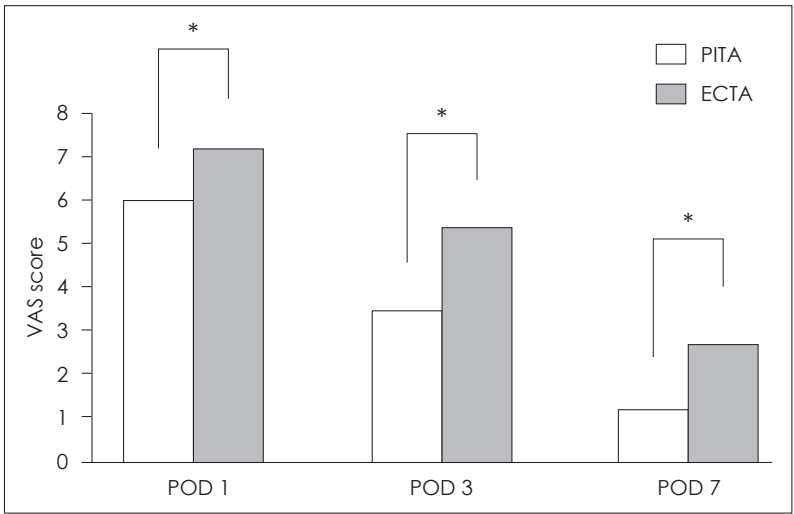

Fig. 2. VAS score of postoperative pain in the PITA and ECTA groups. ${ }^{*} p<0.05$. PITA: powered intracapsular tonsillectomy and adenoidectomy, ECTA: extracapsular tonsillectomy and adenoidectomy, VAS: visual analog scale, POD: postoperative day.

Table 2. Postoperative bleeding cases in the PITA and ECTA groups

\begin{tabular}{lccc}
\hline & PITA $(n=46)$ & ECTA $(n=35)$ & -value \\
\hline $\begin{array}{l}\text { Number of postoperative } \\
\text { bleeding cases }(\%)\end{array}$ & $1(2.2)$ & $2(5.7)$ & 0.575 \\
$\begin{array}{l}\text { Number of readmission } \\
\begin{array}{l}\text { cases due to postoperative } \\
\text { bleeding (\%) }\end{array}\end{array}$ & 0 & $1(2.9)$ & 0.432 \\
& & &
\end{tabular}

PITA: powered intracapsular tonsillectomy and adenoidectomy, ECTA: extracapsular tonsillectomy and adenoidectomy

bleeding was lower in the PITA group compared with the ECTA group, but there was no statistical difference in this study. But bleeding was significantly less in the PITA group in a previously published study. ${ }^{14)}$ This difference is probably because our study was small-sized.

Tissue between tonsil and pharyngeal muscle acts a role in protecting the muscle from thermal damage caused by electrocautery. ${ }^{2,4}$ Postoperative pain is caused by damage to the tonsillar fossa musculature. ${ }^{1)}$ Damage of musculature can be minimized during PITA. Our study found significant decrease of VAS score in the PITA group. Less pain is important because it enables an earlier return to normal diet and life after surgery. ${ }^{4,18)}$

Our study showed patients who received PITA had less postoperative pain. However, as the choice of surgical procedure was determined by the number of episodes of acute tonsillitis, it can be suspected that the ECTA group was more susceptible to postoperative pain. A study by Zagólski, et al. ${ }^{19)}$ shows that the general perception of patients with recurrent tonsillitis having more post-operative pain may be due to intra-operative trauma rather than past medical history. When patients with or without recurrent tonsillitis received the same surgical tech- nique which eliminated forceful dissection, the group with recurrent tonsillitis experienced less pain. Thus it can be argued that the PITA group experienced less pain due to its surgical procedure.

Our study has several limitations. Although the gold standard diagnostic method of OSA is polysomnography, we diagnose OSA subjectively using history taking, physical examination, and questionnaire. Polysomnography is expensive and difficult to perform for younger children because they can't cooperate. Second, we followed up patients until 1 mouth after surgery in outpatient, so our study did not include long-term outcome of PITA. PITA has several advantages because it preserves the tonsillar capsule, but it may lead to a residual tonsil tissue. This residual tonsil enables regrowth and can cause repeated tonsillitis and recurrent of OSA. Therefore, long-term outcome is important, but it was not evaluated in this study. Long-term studies in larger group patients are needed. Third, as complete blindfold could not be achieved by study design, there may be some placebo effect in place. Fourth, as patients with a history of recurrent tonsillitis was enrolled for ECTA rather than PITA, the study may be influenced by selection bias.

In conclusion, PITA is shown to be effectiveness and efficiency in pediatric OSA with fewer complications. Especially, when PITA was performed, there was less postoperative pain, which allowed the children to have a faster return to normal diet and activity after surgery. PITA should be considered more in the treatment of pediatric OSA patients because it is a procedure that gives more satisfaction to both parents and children.

\section{Acknowledgments}

None.

\section{Author Contribution}

Conceptualization: Jae-Jun Song. Data curation: Jae-Min Jeon. Formal analysis: Jeong-Rok Kim. Funding acquisition: Jae-Jun Song. Investigation: Seung-Hwan Bang. Methodology: Jong-Geun Lee. Project administration: Il-Ho Park. Resources: Jae-Min Shin. Software: Jeong-Soo Woo. Supervision: Sung-Won Chae. Validation: Jae-Jun Song. Visualization: Jae-Min Jeon. Writing — original draft: Jeong-Rok Kim. Writing — review \& editing: Jae-Jun Song.

\section{ORCID}

Jae-Jun Song

https://orcid.org/0000-0002-8488-9091

\section{REFERENCES}

1) Kim JS, Kwon SH, Lee EJ, Yoon YJ. Can intracapsular tonsillectomy be an alternative to classical tonsillectomy? A meta-analysis. Otolaryngol Head Neck Surg 2017;157(2):178-89. 
2) Koltai PJ, Solares CA, Koempel JA, Hirose K, Abelson TI, Krakovitz PR, et al. Intracapsular tonsillar reduction (partial tonsillectomy): Reviving a historical procedure for obstructive sleep disordered breathing in children. Otolaryngol Head Neck Surg 2003;129(5):532-8.

3) Koltai PJ, Solares CA, Mascha EJ, Xu M. Intracapsular partial tonsillectomy for tonsillar hypertrophy in children. Laryngoscope 2002;112(S100):17-9.

4) Derkay CS, Darrow DH, Welch C, Sinacori JT. Post-tonsillectomy morbidity and quality of life in pediatric patients with obstructive tonsils and adenoid: Microdebrider vs electrocautery. Otolaryngol Head Neck Surg 2006;134(1):114-20.

5) Tunkel DE, Hotchkiss KS, Carson KA, Sterni LM. Efficacy of powered intracapsular tonsillectomy and adenoidectomy. Laryngoscope 2008;118(7):1295-302.

6) Friedman M, Wilson MN, Friedman J, Joseph NJ, Lin H-C, Chang $\mathrm{H}-\mathrm{W}$. Intracapsular coblation tonsillectomy and adenoidectomy for the treatment of pediatric obstructive sleep apnea/hypopnea syndrome. Otolaryngol Head Neck Surg 2009;140(3):358-62.

7) Reilly BK, Levin J, Sheldon S, Harsanyi K, Gerber ME. Efficacy of microdebrider intracapsular adenotonsillectomy as validated by polysomnography. Laryngoscope 2009;119(7):1391-3.

8) Acevedo JL, Shah RK, Brietzke SE. Systematic review of complications of tonsillotomy versus tonsillectomy. Otolaryngol Head Neck Surg 2012;146(6):871-9.

9) Bitar MA, Rameh C. Microdebrider-assisted partial tonsillectomy: Short- and long-term outcomes. Eur Arch Otorhinolaryngol 2008;265(4):459-63.

10) Choi JH, Lee SH, Lee HM, Lee JK, Kwon SY, Shin C, et al. Correlation between quality of life and personality, behavior problem in children with sleep disordered breathing. Korean J Otorhinolaryngol-Head Neck Surg 2005;48(10):1235-41.

11) Franco RA Jr, Rosenfeld RM, Rao M. Quality of life for children with obstructive sleep apnea. Otolaryngol Head Neck Surg 2000;123(1):9-16.

12) Suen JS, Arnold JE, Brooks LJ. Adenotonsillectomy for treatment of obstructive sleep apnea in children. Arch Otolaryngol Head Neck Surg 1995;121(5):525-30.

13) Chang T-S, Chiang RP-Y. Total analysis of clinical factors for surgical success of adenotonsillectomy in pediatric OSAS. Eur Arch Otorhinolaryngol 2017;274(1):561-6.

14) Vicini C, Eesa M, Hendawy E, Pari M, D'Agostino G, AlGhamdi S, et al. Powered intracapsular tonsillotomy vs. conventional extracapsular tonsillectomy for pediatric OSA: A retrospective study about efficacy, complications and quality of life. Int J Pediatr Otorhinolaryngol 2015;79(7):1106-10.

15) Yosunkaya S, Kutlu R, Cihan FG. Evaluation of depression and quality of life in patients with obstructive sleep apnea syndrome. Niger J Clin Pract 2016;19(5):573-9.

16) Coman AC, Borzan C, Vesa CS, Todea DA. Obstructive sleep apnea syndrome and the quality of life. Clujul Med 2016;89(3):390-5.

17) Bender B, Blassnigg EC, Bechthold J, Kral F, Riccabona U, Steinbichler T, et al. Microdebrider-assisted intracapsular tonsillectomy in adults with chronic or recurrent tonsillitis. Laryngoscope 2015;125(10):2284-90.

18) Chang KW. Intracapsular versus subcapsular coblation tonsillectomy. Otolaryngol Head Neck Surg 2008;138(2):153-7.

19) Zagólski O, Gajda M, Stręk P, Kozlowski MJ, Gądek A, Nyzio J. Adult tonsillectomy: Postoperative pain depends on indications. Braz J Otorhinolaryngol 2016;82(5):589-95. 